DOI: $10.17805 /$ zpu.2016.2.2

\title{
Молодежная политика: концепция И. М. Ильинского
}

\author{
ВАЛ. А. ЛУКОВ \\ (МОСКОВСКИЙ ГУМАНИТАРНЫЙ УНИВЕРСИТЕТ)
}

В статье обобщаются основные положения концепции молодежной политики, выдвинутой И. М. Ильинским. Рассматривается динамика становления и развития концепции на протяжении трех десятилетий начиная с доклада ученого в 1986 г., когда был выдвинут тезис о необходимости такого направления государственной деятельности, до работ 2010-х годов.

Общесоциологическая концепция молодежи И. М. Ильинского выявляет существо его авторской концепции молодежной политики и критической оценки ее осуществления в современных российских условиях. В статье обосновывается характеристика теоретических положений трудов И. М. Ильинского о молодом поколении как гуманистической концепции молодежи. Показывается, что из этой концепции вытекает суть молодежной политики, которая И. М. Ильинским определяется как способ регулирования межпоколенческих отношений, управления процессом преемственности поколений.

Ключевые слова: молодежь; молодежная политика; социология молодежи; теория молодежной организации; закон о молодежи; Игорь Михайлович Ильинский

\section{ВВЕАЕНИЕ}

C тановление теории и практики реализации государственной молодежной политики в СССР и развитие этого направления деятельности государства в Рос-сии в постсоветский период непосредственно связаны с именем Игоря Михайловича Ильинского. Он многие годы возглавлял крупнейший в СССР научно-исследовательский центр по молодежной проблематике (НИЦ при ВКШ, затем НИЦ при Институте молодежи), осуществлявший под его руководством масштабные социологические и междисциплинарные исследования молодежи. Как исследователь проблем молодежи он получил широкое признание в научной среде, а также в кругу политических и общественных деятелей в нашей стране и за рубежом. Часть исследований, осуществлявшихся в НИЦ, ушла в историю, не осталась в современном научном дискурсе о молодом поколении и известна сегодня разве что историкам науки. Но концептуальные работы И. М. Ильинского избегли все смывающий поток времени и переоценки ценностей, оказались созвучными научным поискам, которые в сфере молодежных исследований и в практической работе с молодежью ведутся в условиях новой социальной реальности XXI в. Его обобщающая монография «Молодежь и молодежная политика» (Ильинский, 2001), по данным Российского индекса научного цитирования (РИНЦ), - одна из наиболее цитируемых работ по молодежной проблематике.

Само это обстоятельство заслуживает внимания. Обобщающие работы И. М. Ильинского по теории молодежной организации относятся к концу 1970-х - началу 1980-х годов, когда на основе философского осмысления исторического опыта В $\Lambda$ КСМ он развил представление о сущности молодежной организации и ее функциональном назначении в обществе (Ильинский, 1979, 1981). 3десь немалый интерес представляет то, что в своих работах о комсомоле он опирался на всеобщую организационную науку А. А. Богданова, хотя «Тектология» была в то время доступна только в спецхране, а основываться на ее положениях было серьезным вызовом официальной науке о научном управлении обществом (переиздание основного труда А. А. Богдано- 
ва было осуществлено только в 1989 г., см.: Богданов, 1989). Трактовка И. М. Ильинским сущности и функций молодежной организации определила принятую в системе подготовки и переподготовки кадров комсомола теоретическую концепцию комсомольского строительства - новой для своего времени научной и образовательной дисциплины, корпус основных положений которой представлен в коллективном труде «Комсомольское строительство», подготовленном в качестве учебного пособия под руководством И. М. Ильинского и опубликованном в 1984 г. издательством «Молодая гвардия» большим тиражом (Комсомольское строительство, 1984). Основные главы учебного пособия написаны И. М. Ильинским. Нельзя не заметить, что сама подготовка этого издания шла в условиях острой полемики по вопросам комсомольского строительства, некоторые стороны которой отражены в литературе (Ильинский, Заречкин, 1984; Сулемов, 1982).

Работа над теорией молодежной организации сформировала у ее автора потребность проникнуть глубже в существо молодежной проблематики и в то же время понять ее необходимую связь с задачами чисто практическими - теми, что призван был решать комсомол как организация молодежи и для молодежи (Ковалева, 2006). Это логически вело И. М. Ильинского к разработке теоретических концепций молодежи и молодежной политики.

О содержании этих концепций и их влиянии на теорию и практику работы с молодежью, а также на понимание задач образования в современных условиях имеется обширная литература (Гуманитарное знание ... , 2006; Плаксий, 2006; Ситаров, 2006; Жизнь как Аолг ..., 2007; Меркулов, 2013), мы также неоднократно обращались к освещению вклада И. М. Ильинского в развитие теорий молодежи и в формирование современной концепции молодежной политики (Ауков, 2006ab, 2007, 2008, 2012, 2013, 2014). В настоящей статье мы делаем попытку обобщить основные положения концепции молодежной политики, выдвинутой И. М. Ильинским, в динамике ее становления и развития на протяжении трех десятилетий начиная с его доклада 1986 г., где был выдвинут тезис о необходимости такого направления государственной деятельности (Ильинский, 1986, 1987), до работ 2010-х годов.

\section{ЗАКОН О МОАОАЕЖИ И ПРОБАЕМЫ МОАОАЕЖИ}

Важным этапом в развитии отечественных теоретических концепций молодежи стала работа над Законом о молодежи - правовым нормативным актом, который был призван закрепить юридическими средствами определенное содержание молодежной политики, проводимой в стране. В действительности в отечественной правовой практике такое словосочетание в значении юридического термина применяется редко, оно встречается в некоторых региональных актах законодательства. Пример в свое время дал Татарстан, где еще в 1993 г. был принят Закон Республики Татарстан от 19 октября 1993 г. № 1983-XII «О молодежи» (с последующими изменениями, в том числе и в названии, действует и ныне). Практика утвердилась в законодательстве и других регионов. Например, Законодательным собранием Свердловской области был принят Закон Свердловской области от 29 октября 2013 г. № 113-О3 «О молодежи в Свердловской области». Но на федеральном уровне законодатель не пошел по этому пути, хотя прецедентов в законодательстве других стран не так мало. Это отражает разные подходы к содержанию такого правового акта. Однако в социально-философских, социологических, политологических исследованиях это вполне принятое обозначение и отдельных актов законодательства обобщающего характера, отражающего ос- 
нования молодежной политики, и особой кониептуальной законотворческой идеи, что ярко отразилось в научном творчестве И. М. Ильинского.

Следует заметить, что впервые в нашей стране работа над Законом о молодежи была начата еще в 1966 г. Тогда был создан первый проект такого закона, построенный как собрание норм различных отраслей права и отраслей законодательства, относящихся к молодежи, и имевший скорее политическое, чем правовое назначение. Он не был представлен для обсуждения в высшем законодательном органе власти. Такой же была и судьба второго законопроекта, подготовленного группой авторов, включая и видных юристов, в 1977 г. Тексты этих законопроектов опубликованы в двухтомном издании документов государственной молодежной политики, осуществленном по инициативе И. М. Ильинского (Закон о молодежи, 2008). Их анализ с позиций правотворчества показывает, что причины неудачи надо искать прежде всего в концептуальном решении, не учитывавшем сложившуюся структуру права. Конечно, определенные коррективы в законотворческий процесс тогда вносились и ввиду конкретных обстоятельств, мешавших принятию закона (в частности, в отношении второго законопроекта такую роль сыграло принятие новой Конституции СССР, что требовало внести существенные изменения в подготовленный текст). И все же более существенным было то, что законопроект в первой и второй версиях в концептуальном плане был не проработан и не отражал реальностей советского общества, в своей основе это была декларация о доступности для советской молодежи всех общественных благ.

Выдвигая идею создания Закона о молодежи в третьей версии, И. М. Ильинский учитывал неудачу двух предыдущих попыток. В его инициативе изначально предусматривалось, что чисто юридическими средствами данный закон не может быть создан, нужна, во-первых, реалистическая теория молодежи, которая предполагает и реалистические правовые средства регулирования отношений, в которых участвует молодежь, во-вторых, определенная и концептуально оформленная государственная деятельность в этой сфере, а именно государственная молодежная политика.

В чем же существо концепции молодежи, выдвинутой И. М. Ильинским и примененной в ходе работы над Законом о молодежи в его третьей версии, которая и была принята? Совокупность теоретических постулатов относительно молодого поколения, выдвинутых ученым, есть основания определить как гуманистическую конщепиию молодежи. В ней развитие личности молодого человека, формирование его жизнеспособности поставлено на первое место, причем упор сделан на самоорганизацию, самореализацию, самовыражение молодежи в обществе.

Внимание к проблемам человеческого начала в социологии, как известно, пронизывало «понимающую социологию» М. Вебера, оно же позволило назвать «гуманистической социологией» теоретическую конструкцию Ф. Знанецкого, своего рода гуманистический императив характерен для личностно-ориентированной социологии П. Бергера. Называя концепцию молодежи Ильинского гуманистической, мы имеем в виду не ее связь с этими и другими источниками из мира социологических идей и текстов, а доминанту личностного роста и самореализации молодого человека, которая отодвигает с переднего плана прагматический подход к молодежи как к ресурсу общественного прогресса.

Взгляды И. М. Ильинского приобретали концептуальный характер в период его работы в 1984-1994 гг. директором упомянутого выше НИЦ, тогда ведущего научного учреждения, координировавшего исследования молодежи в СССР. Это был период 
активных теоретических поисков в исследованиях молодежи и у нас, и за рубежом. Широкие контакты НИЦ со специализировавшимися на молодежной проблематике исследовательскими коллективами и группами в Болгарии, Венгрии, Германии (тогда ГАР и ФРГ), Испании, Польше, Румынии, Финляндии, Франции, США, Японии и других странах, сотрудничество с ведущими с учеными, среди которых Петр-Эмил Митев и Петр Балкански (Болгария), Ажим Риордан (Великобритания), Тамотцу Сенгоку (Япония), Мариан Бальцерек (Польша) и др., создали благоприятную почву для представления и обсуждения молодежной проблематики как в ее общих, так и частных аспектах. Позиции Ильинского, некоторое время бывшего одним из руководителей Исследовательского комитета 34 «Социология молодежи» Международной социологической ассоциации, получили известность и признание в научных кругах. Немаловажно, что Ильинский с середины 1970-х годов оказался в центре активной работы по соединению усилий специалистов в области молодежных исследований в масштабах страны: в 1975 г. был создан Общественный совет по координации научных исследований проблем молодежи при ЦК ВАКСМ и Академии педагогических наук СССР, a c 1985 г. в состав его учредителей вошли также АН СССР и Минвуз СССР. В 1985-1991 гг. главным ученым секретарем Совета был Ильинский. В Совете и НИЦ как его базовой организации взаимодействовали практически все крупные советские исследователи молодежи - московские, ленинградские, уральские, киевские, минские, прибалтийские и др.

Научный фон, на котором складывалась теоретическая концепция молодежи Ильинского, нельзя не учитывать не только в смысле рамок, которые каждая историческая эпоха задает исследователю, но и в смысле влияния исследований о молодежной организации, о комсомоле. Этим пластом междисциплинарного знания представители академической науки, по существу, не владели, и его роль для понимания молодежи преуменьшали. Многие дискуссии того времени о комсомоле сегодня представляются непродуктивными. Например, ожесточенное противостояние тех, кто считал, что комсомол возник по инициативе самой коммунистической молодежи, и тех, кто считал, что он был создан партией большевиков, сегодня напоминает споры средневековых схоластов. Или дискуссия о том, считать воспитание молодежи, осуществляемое в СССР, коммунистическим или социалистическим. Реальные же противоречия затушевывались. Например, идея комсомола как организованного отряда передовой советской молодежи трудно сочеталась с задачей массового приема в ряды ВАКСМ. На литературе о комсомоле и молодежи тех лет не могли не сказаться партийные установки, которые подталкивали авторов быть излишне пафосными в отношении партии, советской власти, комсомола, в идеологическом смысле - сохранять безусловную верность марксизму-ленинизму, в научном отношении - быть осторожными в оценках, минимизировать теоретико-методологические новации.

И все же, прорывая барьеры дозволенного, И. М. Ильинский строит свое исследование комсомола как молодежной организации, тесно связанной с осуществлением государственной власти и даже наделенной отдельными властными полномочиями, но в то же время имеющей общественную (негосударственную) природу. Что әто за феномен? Каков потенциал такого общественного объединения для решения социальных проблем общества в целом и молодежи в частности? В чем специфика общественного объединения молодежи, когда оно достигает масштаба своего организационного развития и масштаба деятельности, требующего мощной системы управления? 
Какой должна быть система управления такой организации с учетом экономических, социальных, культурных различий молодых людей и мест их проживания и деятельности? Как в таком случае сочетаются самоорганизация и управленческая иерархия? Все эти вопросы сегодня следует рассматривать в контексте теории организации, и разработка Ильинским проблем места и роли В $\Lambda$ КСМ в советском обществе сохраняет свою ценность прежде всего в той части, в которой раскрывает организацию не как «машину» или «общину», что свойственно западной социальной науке, а как целевую общность, активно влияющую на свою социальную среду.

Таким образом, к гуманистической концепции молодежи ее автор шел не по широко принятому пути теоретических раздумий о молодости, ее преходящем характере, особых чертах молодежи, проявляющихся в смене поколений, а по пути осмысления деятельностного начала молодежи в обществе как самонастраивающемся и самоуправляемом организме. Специфика концепции Ильинского состоит в том, что концепция существует не сама по себе как еще одна теория молодежи, а как обоснование определенной линии в области разработки и осуществления молодежной политики, выявления ее стратегической составляющей. Широкая постановка вопроса о положении молодежи приводит исследователя к убеждению, что необходима современнал, отвечаюшал запросам XXI в., конщепиия молодежи, которая, в свою очередь, не может быль создана без новой философии возраста. Эта философия и основанная на ней концепция молодежи будут складываться из системы универсальных общепринятых среди ювенологов мира научных истин о молодежи как особой категории общества, которые являются общечеловеческим достоянием, а также идей и знаний о молодежи конкретных обществ (Ильинский, 2016: 81).

\section{БАЗОВЫЕ ПОАОЖЕНИЯ КОНЦЕПЦИИ ИАЬИНСКОГО}

В ряде работ И. М. Ильинский формулирует свою концепцию молодежи. Он, собственно, не стремится к созданию чисто теоретической модели. Базовые положения концепции представлены в упоминавшейся монографии «Молодежь и молодежная политика», в вводных и заключительных главах монографий, готовившихся как своего рода «научное зеркало» государственных докладов о положении молодежи, первые два из которых создавались под руководством И. М. Ильинского. Концептуальный характер носят положения, вошедшие в книгу «Молодежь планеты: глобальная ситуация в 90-х годах, тенденции и перспективы», которая включает разделы, подготовленные И. М. Ильинским для доклада, написанного по поручению Генерального секретаря ООН (Молодежь планеты ..., 1999). Некоторые позиции вычленяются из научного творчества И. М. Ильинского аналитическим путем.

В целом к базовым положениям гуманистической концепции молодежи И. М. Ильинского мы относим следующие.

Молодежь - это объективное общественное явление, выступающее всегда как большая специфическая возрастная подгруппа. Ключом к познанию природы молодежи является диалектика целого и части ( «молодежь - часть общества; молодежь часть общества»). Специфические, обусловленные возрастом проблемы молодежи в любом обществе состоят в том, что (а) молодость тесно связана с идеей зависимости; (б) большая часть молодежи (учащиеся, студенты и т. п.) еще не включена в процесс производства и потому «живет в кредит»; (в) большинство молодых людей не обладают личной самостоятельностью в принятии решений, касающихся их жизни; (г) перед молодыми дюдьми стоит проблема выбора сферы трудовой деятельности, 
выбора профессии; (А) молодые люди решают проблему нравственного и духовного самоопределения; (е) они решают проблему брачного выбора и деторождения.

Молодежь по природе двойственна: она - явление биологическое и сочиальное, что определяет связь ее психофизического и социального развития.

Молодежь - явление конкретно-историческое. Это означает, что для каждого конкретного общества может быть предложено свое определение молодежи на основе общего понимания этого феномена.

Молодежь - это носитель огромного интеллектуального потенциала, особых способностей $к$ творчеству.

Молодежь одновременно объект и субъект соииализации, что определяет ее социальный статус.

Молодежь обретает субъектность по мере самоидентификации, самоосознания своих интересов, роста своей организованности.

Молодежь - носитель процессов, которые развернутся в полную мощь в будущем.

Молодежь - объект комплексных, междисииплинарных исследований, которые только в своей совокупности могут дать достаточно достоверную картину о ней (там же: 81-91).

Пафос концепции Ильинского составляет положение о том, что молодежь - это ценность особого рода, это главная ценность общества, это понятие не только демографическое, но также экономическое, социальное, политическое (там же: 52). Если в обществе, в деятельности государства делается ставка на молодежь, то этим изменяется не только будущее, но и настоящее, поскольку политика начинает строиться с опорой на управление процессами, на опережение событий, оттесняя политику запоздалых реакций на уже случившееся.

Центральное звено концепции Ильинского составляет идея субъектности молодежи. Близкая позиция разрабатывалась в трудах болгарского исследователя П.-Э. Митева, выдвинувшего концепцию реализации и самореализации молодежи. Она в той или иной мере представлена в трудах польских исследователей М. Карвата и В. Миляновского, ряда российских исследователей. Молодежь не только объект воспитания, но и субъект исторических изменений - так в 1980-е годы пишут многие ученые, специализирующиеся на исследованиях проблем молодежи. Но Ильинский идет гораздо дальше, говоря о субъектности молодежи. Проблема, утверждает он, состоит в том, что мир решительно меняется, идут процессы, которые не могут быть в достаточной мере осмыслены и тем более взяты под контроль старшим поколением. В этих условиях вопрос состоит не в том, чтобы поделиться субъектностью с молодежью, но опереться на субъектность молодежи, чтобы вытянуть иелое - все общество, его настоящее и будущее. Это концептуальное переосмысление роли молодежи и молодежного движения в новых социальных и культурных обстоятельствах: «открытие» субъектной роли молодежи в масштабах общества и есть необходимое условие, предваряющее эффективную реализацию социальной субъектности молодежи.

Концепция Ильинского, несомненно, сформировалась в ключе современных философских представлений о глобализации мировых тенденций. Собственно, когда говорят о вызовах глобализации, должно быть ясно, что она бросает вызов именно молодежи - и не только завтра, но и сегодня. Отсюда, между прочим, вытекает новая парадигма образования, которая призвана преодолеть в подрастающих поколениях негативные следствия глобализации в ее нынешних реалиях - «глобализации по-американски». Эту парадигму Ильинский формулирует в книге «Образовательная 
революция» (Ильинский, 2002). Вывод автора таков: в ситуации, когда глобализация по-американски стала основным фактором неустойчивого развития и все более делает привычным абсурд Происходящего, когда мир становится все более неопределенным и непредсказуемым, образование призвано стать средством спасения. Оно должно носить упреждающий, опережающий характер, способствовать конструированию и строительству новой реальности. Это означает и смену приоритетов: по Ильинскому, новая парадигма образования по своему содержанию является прежде всего гуманитарной.

Гуманитарное начало - в целом определяющая черта концептуальных работ И. М. Ильинского о молодежи. Это с очевидность проявилось и в гуманистической концепции молодежи. Отсюда и выстроено автором понимание того, что и концепция молодежной политики не должна быть просто набором организационных решений, в ней существен стратегический замысел, который, по Ильинскому, и должен состоять в том, чтобы восстановить взаимодействие поколений, в котором развились обширные кризисы. Соответственно, суть молодежной политики им определялась так: "Сознательная, челенаправленная молодежная политика и есть способ регулирования межпоколенческих отношений, управления прочессом преемственности поколений и, стало бътьь, развития общества (Ильинский, 2016: 436). Означенная формула отражает смысл молодежной политики во все времена, во всех обществах.

Ныне, по мнению И. М. Ильинского, осознания того, что молодежная политика нужна для успешного продвижения России вперед, недостаточно. Проблема заострилась до предела. Автор утверждает в работах последнего времени: о молодежи сегодня необходимо говорить $\boldsymbol{b}$ категориях войны. Эта война - прямое продолжение проигранной Советским Союзом холодной войны. Противник имеет разработанные планы, вкладывает в российскую молодежь огромные материальные ресурсы. Он рассчитывает на передел мира без военного вмешательства: не нужен захват территорий, нужно работать с молодежью, которую нужно «перекультурить». Эта враждебная России молодежная политика дает свои результаты. Ильинский подчеркивает: «Молодежная политика - это центральное звено политики национальной безопасности, берущей начало в настоящем и обращенной - от поколения к поколению - в далекое будущее» (Ильинский, 2016: 310).

В статье И. М. Ильинского «О критериях эффективности молодежной политики», опубликованной в журнале «Наша молодежь» в 2009 г., представлена масштабная программа действий органов государственной власти, структур гражданского общества по решению стратегических вопросов социального развития страны в опоре на молодое поколение (Ильинский, 2009). Это своего рода переложение гуманистической концепции молодежи и ее сегмента - концепции государственной молодежной политики на язык организационных действий.

В том же направлении может быть рассмотрена и концепция воспитания жизнеспособных поколений, выдвинутая И. М. Ильинским и включенная как приложение во второй государственный доклад о положении молодежи в Российской Федерации, посвященный проблемам воспитания молодежи (Молодежь России ... , 1995), что в это время шло вразрез с распространявшимся в обществе и органах государственной власти представлением о ненужности воспитательного воздействия на молодое поколение. Функция воспитания была изъята из системы высшего образования, значительно ослаблена во всей образовательной деятельности; в 2014-2015 гг. наметился поворот в отношении органов государственной власти к воспитанию, кото- 
рое рассматривается ныне как приоритет в развитии страны, хотя процесс возвращения воспитания в систему государственной деятельности идет трудно (Ильинский, Ауков, 2015).

\section{ЗАКАЮЧЕНИЕ}

И. М. Ильинский выдвинул оригинальные концепции, которые были им положены в научное обоснование нового направления деятельности органов государственной власти - государственной молодежной политики. С его именем связаны разработка и принятие Закона СССР «Об общих началах государственной молодежной политики в СССР» (1991 г.), в котором его концептуальные положения о молодежи и молодежной политике были закреплены и во все последующие годы, уже в современной России оставались важным ориентиром при разработке государственными органами, политическими партиями, общественными объединениями стратегий, доктрин, программ и других основополагающих документов в области молодежной политики.

Многолетний опыт работы И. М. Ильинского и его коллег над концепцией молодежи и молодежной политики показывает, что работа эта не может проходить лишь в чисто академической манере и оцениваться по правилам построения научных теорий. Только в соединении с насущными задачами самореализации человека в его лучших свойствах и чертах, только в связи с осознанными действиями общества по сохранению себя в новых поколениях, восхождению через молодых к более высоким уровням социального развития имеет смысл разрабатывать теории молодежи и основные направления молодежной политики.

В гуманистической концепции молодежи, концепции государственной молодежной политики Ильинского, его исследованиях молодежных проблем в полной мере отразилась личность ее автора. Ильинский, поэт, романтик в жизни, в философии реалист, он исходит не из изучения внутринаучных тенденций, а наблюдает жизнь, обобщает, концептуализирует эти наблюдения. Ильинский обнаружил новое качество ситуации, отсюда и проистекают его основные идеи молодежной политики (поддержка самоопределения молодежи, отказ от патернализма, который в новых условиях перестал быть эффективным). В повседневных наблюдениях и размышлениях о жизни он выявил черты надвигающейся глобализации как реальности, и его внимание к глобальному миру и его вызовам имеет своим источником не труды по глобалистике, а осмысление фактов и тенденций, доступных и для других, но не замеченных, не оцененных должным образом. На этой основе складывается его социальная философия Происходящего - эффективная система адекватного реальности теоретического мышления в переходный период, если это мышление рассматривать как основу успешного практического действия.

\section{СПИСОК АИТЕРАТУРЫ}

Богданов, А. А. (1989) Тектология: (Всеобщая организационная наука) : в 2 кн. / редкол.: А. И. Абалкин (отв. ред.) и др. М. : Экономика. Кн. 1. 304 с.; Кн. 2. 351 с.

Гуманитарное знание: перспективы развития в XXI веке (2006) : В честь 70-летия Игоря Михайловича Ильинского / под общ. ред. В. А. Аукова. М. : Изд-во Нац. ин-та бизнеса. 680 с.

Жизнь как Аолг : Юбилей И. М. Ильинского (2007). М. : Изд-во Моск. гуманит. ун-та. 252 с.

Закон о молодежи (2008) : Аокументы и материалы по истории становления государственной молодежной политики в России : в 2 т. / сост. и авт. вступ. ст. И. М. Ильинский, В. А. Ауков. М. : ИзА-во Моск. гуманит. ун-та. Т. 1.543 с.; Т. 2.556 с. 
Ильинский, И. М. (1979) ВАКСМ в политической системе советского общества // Некоторые вопросы места и роли В $\Lambda$ КСМ в политической системе развитого социализма : сб. науч. тр. / ВКШ при ЦК ВАКСМ, НИЦ. М. 141 с. С. 56-72.

Ильинский, И. М. (1981) ВАКСМ в политической системе советского общества. М. : Молодая гвардия. 239 с.

Ильинский, И. М. (1986) Резервы комсомольской демократии // Молодой коммунист. № 12. С. 7-15.

Ильинский, И. М. (1987) Проблемы молодежи и молодежной политики в условиях ускорения социально-экономического развития советского общества // Молодежь-86 : сб. ст. / НИЦ

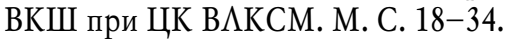

Ильинский, И. М. (2001) Молодежь и молодежная политика: Философия. История. Теория. М. : Голос. 694 с.

Ильинский, И. М. (2002) Образовательная революция. М. : Изд-во Моск. гуманит.-социальн. академии. 592 с.

Ильинский, И. М. (2009) О критериях эффективности молодежной политики // Наша молодежь. № 1. С. 5-7.

Ильинский, И. М. (2016) Молодежь. Молодежная политика. Молодежная организация. М. : Терра. 672 с.

Ильинский, И. М., Заречкин, Ю. В. (1984) Теоретико-методологические вопросы комсомольского строительства. Некоторые итоги дискуссии по проблемам комсомольского строительства // Вопросы теории и практики комсомольского строительства в современных условиях : сб. науч. тр. / ВКШ при ЦК ВАКСМ. М. 240 с. С. 3-15.

Ильинский, И. М., Ауков, В. А. (2015) О стратегии развития воспитания в Российской Федерации на период до 2025 года [Электронный ресурс]// Научные труды Московского гуманитарного университета. № 1. URL: http://journals.mosgu.ru/trudy/article/view/6 (дата обращения: 12.03.2016). DOI: http://dx.doi.org/10.17805/trudy.2015.1.6

Ковалева, А. И. (2006) От комсомольского строительства к теории организаций // Знание. Понимание. Умение. № 3. С. 21-24.

Комсомольское строительство (1984) : учеб. пособие / авт. кол. : И. М. Ильинский (рук.) [и др.]. М. : Молодая гвардия. 574 с.

Иуков, В. А. (2006b) Игорь Михайлович Ильинский: вклад в науку // Знание. Понимание. Умение. № 3. С. 6-13.

Иуков, В. А. (2006а) Ильинский: гуманистическая концепция молодежи // Знание. Понимание. Умение. № 2. С. 48-59.

Ауков, В. А. (2007) И. М. Ильинский о молодежи и молодежной политике // Социально-гуманитарные знания. № 5. С. 158-172.

Ауков, В. А. (2008) Ильинский Игорь Михайлович // Социология молодежи : энциклопедич. словарь / отв. ред. Ю. А. Зубок, В. И. Чупров. М. : Academia. 606 с. С. 148-149.

Ауков, В. А. (2012) Теории молодежи: Междисциплинарный анализ. М. : Канон + РООИ «Реабилитация». $528 \mathrm{c.}$

Ауков, В. А. (2013) Ильинский Игорь Михайлович о проблемах молодежи и молодежной политики // Youth World Politic. № 2. C. 107-111.

Иуков, В. А. (2014) Ильинский Игорь Михайлович // Знание. Понимание. Умение. № 3. С. 389-397.

Меркулов, П. А. (2013) Государственная молодежная политика России - исторические этапы формирования. СПб. : Алеф-Пресс. 516 с.

Молодежь планеты: глобальная ситуация в 90-х годах, тенденции и перспективы (1999) / И. М. Ильинский и др. ; рук. авт. кол., науч. ред. И. М. Ильинский. М. : Ин-т молодежи ; Голос. 323 с.

Молодежь России: воспитание жизнеспособных поколений (1995) : докл. Ком. РФ по делам молодежи / авт. кол.: И. М. Ильинский [и др.] ; Ком. РФ по делам молодежи. М. 256 с. 
Плаксий, С. И. (2006) Образовательная парадигма Ильинского и стратегия успешного вуза // Знание. Понимание. Умение. № 3. С. 13-18.

Ситаров, В. А. (2006) Воспитание жизнеспособных поколений: позиция И. М. Ильинского // Знание. Понимание. Умение. № 3. С. 24-28.

Сулемов, В. А. (1982) Союз молодых борцов: Теория, исторический опыт и современные проблемы комсомольского строительства. 2-е изд., доп. и перераб. М. : Молодая гвардия. 399 с.

Аата поступления: 15.05.2016 г.

\section{I.M. ILINSKIY'S CONCEPTION OF YOUTH POLICY \\ VAL. A. LUKOV \\ (MOSCOW UNIVERSITY FOR THE HUMANITIES)}

The article summarizes the main provisions of the conception of youth policy developed by Igor' Mikhailovich Ilinskiy, focusing on the development of his theory for over three decades, from the paper presented in 1986, which argued for introducing youth policy as a new direction of state activity, to Ilinskiy's latest contributions.

The general sociological conception of youth as advanced by I.M. Ilinskiy sheds light on the core features of his theory of youth policy and on his critique of its current implementation in Russia. We argue that I.M. Ilinskiy's theoretical works feature a humanist concept of youth which forms the core of his youth policy theory understood as a way of regulating intergenerational relations and guaranteeing intergenerational continuity.

Keywords: youth; youth policy; sociology of youth; theory of youth organization; youth legislation; Igor' Mikhailovich Ilinsky

\section{REFERENCES}

Bogdanov, A. A. (1989) Tektologiia: (Vseobsbchaia organizatsionnaia nauka) [Tectology: a universal organizational science]: in 2 vols., ed. L. I. Abalkin et al. Moscow, Ekonomika Publ. Bk. 1. 304 p.; Bk. 2. 351 p. (In Russ.).

Gumanitarnoe znanie: perspektivy razvitiia $v$ XXI veke (2006) : V chest' 70-letiia Igoria Mikbailovicha Il'inskogo [The humanities: prospects of development in the 21st century: A festschrift for Igor' Mikhailovich Ilinskiy's 70th birthday], ed. V. A. Lukov. Moscow, National Institute of Business Publ.. 680 p. (In Russ.)

Zbizn' kak Dolg : Iubilei I. M. Il' inskogo (2007) [Life as Duty: I.M. Ilinskiy's Anniversary]. Moscow, Moscow University for the Humanities Publ.. 252 p. (In Russ.)

Zakon o molodezhi (2008): Dokumenty $i$ materialy po istorii stanovleniia gosudarstvennoi molodezhnoi politiki $v$ Rossii [The Law on Youth: Documents and materials on the history of state youth policy in Russia]: in 2 vols., ed. I. M. Ilinskiy, V. A. Lukov. Moscow, Moscow University for the Humanities Publ. Vol. 1. 543 p.; Vol. 2. 556 p. (In Russ.).

Ilinskiy, I. M. (1979) VLKSM v politicheskoi sisteme sovetskogo obshchestva [VLKSM in the political system of the Soviet society]. In: Nekotorye voprosy mesta i roli VLKSM v politicheskoi sisteme razvitogo sotsializma: sb. nauch. $t r$. [VLKSM's place and role in the political system of developed socialism: A collection of articles]. Moscow, Research Center at the Higher School of Komsomol Publ. 141 p. Pp. 56-72. (In Russ.).

Ilinskiy, I. M. (1981) VLKSM v politicheskoi sisteme sovetskogo obsbchestva [VLKSM in the political system of the Soviet society]. Moscow, Molodaia gvardiia Publ. 239 p. (In Russ.).

Ilinskiy, I. M. (1986) Rezervy komsomol'skoi demokratii [Reserves of the Komsomol democracy]. Molodoi communist, no. 12, pp. 7-15. (In Russ.).

Ilinskiy, I. M. (1987) Problemy molodezhi i molodezhnoi politiki v usloviiakh uskoreniia sotsial'no-ekonomicheskogo razvitiia sovetskogo obshchestva [Issues of youth and youth policy during the acceleration of social and political development of Soviet society]. In: Molodezb'-86 : sbornik statei [Youth 1986: A collection of articles]. Moscow, Research Center at the Higher School of Komsomol Publ. Pp. 18-34. (In Russ.). 
Ilinskiy, I. M. (2001) Molodezh' i molodezhnaia politika: Filosofiia. Istoriia. Teoriia [Youth and youth policy: Philosophy. History. Theory]. Moscow, Golos Publ. 694 p. (In Russ.).

Ilinskiy, I. M. (2002) Obrazovatel' naia revoliutsiia [The educational revolution]. Moscow, Moscow Academy for the Humanities and Social Sciences Publ. 592 p. (In Russ.).

Ilinskiy, I. M. (2009) O kriteriiakh effektivnosti molodezhnoi politiki [On the criteria of efficient youth policy]. Nasha molodezb', no. 1, pp. 5-7. (In Russ.).

Ilinskiy, I. M. (2016) Molodezb'. Molodezhnaia politika. Molodezhnaia organizatsiia [Youth. Youth policy. Youth organization]. Moscow, Terra Publ. 672 p. (In Russ.).

Ilinskiy, I. M. and Zarechkin, Yu. V. (1984) Teoretiko-metodologicheskie voprosy komsomol'skogo stroitel'stva. Nekotorye itogi diskussii po problemam komsomol'skogo stroitel'stva [Theoretical and methodological issues of constructing the Komsomol: Outcomes of a discussion on the construction of Komsomol]. In: Voprosy teorii i praktiki komsomol'skogo stroitel'stva $v$ sovremennykb usloviiakb: sb. nauch. $t r$. [Issues of theory and practice of constructing the Komsomol under current conditions: A collection of articles]. Moscow, Higher School of Komsomol Publ. 240 p. Pp. 3-15. (In Russ.).

Ilinskiy, I. M. and Lukov, V. A. (2015) O strategii razvitiia vospitaniia v Rossiiskoi Federatsii na period do 2025 goda [On the strategy of advancing personality development (vospitanie) in the Russian Federation for the period through 2025]. Naucbnye trudy Moskovskogo gumanitarnogo universiteta, no. 1 [online] Available at: http://journals.mosgu.ru/trudy/article/view/6 (In Russ.). DOI: http://dx.doi.org/10.17805/trudy.2015.1.6

Kovaleva, A. I. (2006) Ot komsomol'skogo stroitel'stva k teorii organizatsii [From constructing the Komsomol to a theory of organization]. Znanie. Ponimanie. Umenie, no. 3, pp. 21-24. (In Russ.).

Komsomol'skoe stroitel'stvo (1984) : ucheb. posobie [The construction of Komsomol: A textbook], ed. by I. M. Ilinskiy. Moscow, Molodaia gvardiia Publ. 574 p. (In Russ.).

Lukov, V. A. (2006b) Igor' Mikhailovich Ilinskiy: vklad v nauku [Igor' Mikhailovich Ilinskiy: His contribution to science]. Znanie. Ponimanie. Umenie, no. 3, pp. 6-13. (In Russ.).

Lukov, V. A. (2006a) Ilinskiy: gumanisticheskaia kontseptsiia molodezhi [Ilinskiy: A humanist concept of youth]. Znanie. Ponimanie. Umenie, no. 2, pp. 48-59. (In Russ.)

Lukov, V. A. (2007) I. M. Ilinskiy o molodezhi i molodezhnoi politike [I.M. Ilinskiy on youth and youth policy]. Sotsial'no-gumanitarnye znaniia, no. 5, pp. 158-172. (In Russ.)

Lukov, V. A. (2008) Ilinskiy Igor' Mikhailovich [Ilinskiy Igor' Mikhailovich] In: Sotsiologiia molodezhi : entsiklopedich. slovar' [Sociology of youth: An encyclopedic dictionary], ed. Yu. A. Zubok and V. I. Chuprov. Moscow, Academia Publ. 606 p. Pp. 148-149. (In Russ.).

Lukov, V.A. (2012) Teorii molodezbi: Mezbdistsiplinarnyi analiz [Theories of youth: An interdisciplinary analysis]. Moscow, Kanon + ROOI «Reabilitatsiia» Publ. 528 p. (In Russ.).

Lukov, V. A. (2013) Ilinskiy Igor' Mikhailovich o problemakh molodezhi i molodezhnoi politiki [Ilinskiy Igor' Mikhailovich on youth issues and youth policy]. Youth World Politic, no. 2, pp. 107-111. (In Russ.).

Lukov, V. A. (2014) Ilinskiy Igor' Mikhailovich [Ilinskiy Igor' Mikhailovich]. Znanie. Ponimanie. Umenie, no. 3, pp. 389-397. (In Russ.).

Merkulov, P. A. (2013) Gosudarstvennaia molodezhnaia politika Rossii - istoricheskie etapy formirovaniia [Russia's youth policy: stages of development]. Saint Petersburg, Alef-Press. 516 p. (In Russ.).

Molodezh' planety: global' naia situatsiia v 90-kb godakb, tendentsii i perspektivy (1999) [Youth in the world: Global situation in the 1990s, trends and prospects], ed. I. M. Ilinskiy. Moscow, Institute of Youth Publ.; Golos. 323 p. (In Russ.).

Molodezh' Rossii: vospitanie zhiznesposobnykb pokolenii (1995) : dokl. Kom. RF po delam molodezhi [Russia's youth: Shaping viable generations: A Report at the Youth Affairs Committee of the RF], ed. I. M. Ilinskiy [et al.] ; Youth Affairs Committee of the RF. Moscow. 256 p. (In Russ.).

Plaksii, S. I. (2006) Obrazovatel'naia paradigma Il'inskogo i strategiia uspeshnogo vuza [Ilinskiy's educational paradigm and a strategy for a successful institution of higher education]. Znanie. Ponimanie. Umenie, no. 3, pp. 13-18. (In Russ.). 
Sitarov, V. A. (2006) Vospitanie zhiznesposobnykh pokolenii: pozitsiia I. M. Il'inskogo [Shaping viable generations: The views of I.M. Ilinskiy]. Znanie. Ponimanie. Umenie, no. 3, pp. 24-28. (In Russ.).

Sulemov, V. A. (1982) Soiuz molodykb bortsov: Teoriia, istoricheskii opyt i sovremennye problemy komsomol'skogo stroitel'stva [The union of young fighters: Theory, historical experience and contemporary issues of the construction of Komsomol] 2nd edn, augm. and reworked. Moscow, Molodaia gvardiia Publ. 399 p. (In Russ.).

Submission date: 15.05 .2016

Ауков Валерий Андреевич - доктор философских наук, профессор, директор Института фундаментальных и прикладных исследований Московского гуманитарного университета, заслуженный деятель науки Российской Федерации. Адрес: 111395, Россия, г. Москва, ул. Юности, А. 5. Тел.: +7 (499) 374-75-95. Эл. адрес: v-lukov@list.ru

Lukov Valery Andreevich, Doctor of Philosophy, Professor, Director, Institute of Fundamental and Applied Studies, Moscow University for the Humanities; Honored Scientist of the Russian Federation. Postal address: 5 Yunosti St., Moscow, Russian Federation 111395. Tel.: +7 (499) 374-7595. E-mail: v-lukov@list.ru 